\title{
Benign Ovarian Cyst
}

National Cancer Institute

\section{Source}

National Cancer Institute. Benign Ovarian Cyst. NCI Thesaurus. Code C4927.

A non-malignant ovarian cyst. 